\title{
Historical contingency and spatial processes rather than ecological niche differentiation explain the distribution of invasive goldenrods (Solidago and Euthamia)
}

\author{
Magdalena Szymura • Tomasz H. Szymura
}

Received: 19 January 2016/ Accepted: 5 April 2016/Published online: 13 April 2016

(C) The Author(s) 2016. This article is published with open access at Springerlink.com

\begin{abstract}
The effectiveness of invasion depends on the interacting environmental factors and biology of the invader. The effects of these interactions are contingent on their contexts and difficult to predict. Among the most successful plant invaders in Europe are the goldenrods (Solidago and Euthamia genera). We assessed the roles of ecological niche differentiation and historical contingency on their distribution in Silesia (Central Europe, studied area approximately $32,000 \mathrm{~km}^{2}$ ). The distributions of the two most common species ( $S$. gigantea and S. altissima) were clumped, and the species dominated different areas. The distribution was unrelated to ecological niche differences but originates rather from the history of invasion and subsequent density-dependent spread;
\end{abstract}

Communicated by Scott J Meiners.

Electronic supplementary material The online version of this article (doi:10.1007/s11258-016-0601-1) contains supplementary material, which is available to authorized users.

\section{Szymura $(\bowtie)$}

Department of Agroecosystems and Green Areas

Management, Wrocław University of Environmental and

Life Sciences, Grunwaldzki Sq. 24A, 50-363 Wrocław,

Poland

e-mail: magdalena.szymura@up.wroc.pl

T. H. Szymura

Department of Ecology, Biogeochemistry and Environmental Protection, University of Wrocław, Maksa

Borna Sq. 9, 50-328 Wrocław, Poland the species that was first introduced occupied available habitats and prevented the establishment of other species. Solidago canadensis was distributed randomly throughout the entire region and did not differ from S. altissima in its ecology. Euthamia graminifolia differed from the other goldenrods in habitat preferences and environmental requirements. Its distribution was strongly spatially structured, clumping around initial infestation sites. The extents of the differences resulting from ecological niche differentiation and the limitation of long-range dispersal are unclear. We argue that the under-representation of $E$. graminifolia in abandoned fields originates from the inhibition of establishment in habitats already occupied by other goldenrods. The results underline that the effect of historical contingency can be more prominent than ecological niche differentiation on invasive species distribution and invasion effectiveness.

Keywords Biological invasions - Dispersal limitation · Ecological contingency $\cdot$ Habitat preferences - Invasion effectiveness - Local distribution · Priority effect · Range infilling

\section{Introduction}

Invasions of alien species alter biodiversity, landscape structure, ecosystem functions and services, and the 
local economy, as well as human health and wellbeing (Chapuis-Lardy et al. 2006; Pejchar and Mooney 2009; Hejda et al. 2009; Pyšek and Richardson 2010; Vilà et al. 2011; Hulme et al. 2014, 2015). The total number of invasive species is still increasing, and habitats may be invaded by multiple species (Kuebbing et al. 2013; Kuebbing and Nuñez 2015). Thus, knowledge about the interactions between nonnative species becomes critical for understanding their distribution and abundance, particularly from the perspectives of nature conservation and management (Kuebbing et al. 2013; Kuebbing and Nuñez 2015).

Anthropogenic species movement is the primary driver of plant invasion (Chytrý et al. 2008; Pyšek and Richardson 2010; Kuebbing and Nuñez 2015). However, the subsequent effectiveness of invasion, considered as the efficient distribution and habitat infilling within the new range and/or the abundance of individuals, is driven by the interaction of environmental factors (land-use system, climate, habitat disturbances and resident vegetation) and the biology of the invasive species (Lake and Leishman 2004; Pyšek and Richardson 2008; Catford et al. 2009; van Kleunen et al. 2010; Essl et al. 2011; Johnson et al. 2012; Warren et al. 2013). The effects of these interactions are highly contingent on their context (Chamberlain et al. 2014), e.g. plant community composition of the new territory, specifically the presence of interacting species, availability of suitable space and resources, and the time a population has been established (Putten et al. 2013; Vannette and Fukami 2014; Marchante et al. 2015; Young et al. 2015). Numerous studies of species' interactions indicate that the order of arrival into an ecosystem, the so-called priority effect (Shulman et al. 1983), can influence local community assembly (Fukami 2010; Grman and Suding 2010; Kardol et al. 2013; Putten et al. 2013; Zefferman 2015; Fraser et al. 2015). As a result, ecological contingencies can govern the success of colonisation of dispersing individuals and limit the distribution of invasive species (Ricklefs 2010; Fraser et al. 2015). The priority effect should be particularly strong when interacting species are similar in resource use, or when the early-arriving species strongly affect the environment, and the late-arriving species have resource high requirements (Vannette and Fukami 2014).

One of the most successful worldwide plant invaders are the goldenrods (Pyšek 1998; Weber
2003). Four alien goldenrod species (Solidago and Euthamia) invade Central Europe: S. gigantea Aiton, S. canadensis L., S. altissima L. (S. canadensis var. scabra (Muhl.) Torr. and Gray) and E. graminifolia (L.) Nutt. Alien Solidago species cause the decrease of plant species richness (Hejda et al. 2009; Del Fabbro et al. 2013; Fenesi et al. 2015a; Pal et al. 2015), alter spontaneous succession (Bornkamm 2007; Bartha et al. 2014) and negatively influence the diversity of birds (Skórka et al. 2010) and insects (Moroń et al. 2009). Due to their locally high abundance and substantial environmental impact, their populations need to be controlled (Sheppard et al. 2006; Skórka et al. 2010; Fenesi et al. 2015a).

The native ranges of these species partially overlap but differ in extent: $S$. altissima has the largest range, the ranges of $S$. gigantea and E. graminifolia are similar but narrower than that of $S$. altissima, while the range of $S$. canadensis is relatively the smallest (Weber and Schmid 1998; Weber 2001; Semple and Cook 2006). They are considered as broad tolerant in terms of soil characteristics, but $S$. gigantea is usually associated with moist to wet habitats, while the $S$. altissima is sensitive to flooding (Weber 2000; Abrahamson et al. 2005; Weber and Jakobs 2005). In the native range, several goldenrod species can co-occur, but the particular combination of the species present at one site can vary according to site conditions (Rhoads and Block 2000; Abrahamson et al. 2005). Observation at the local scale in Pennsylvania, USA, showed that S. altissima and S. gigantea were associated with neutral soils, whereas E. graminifolia achieved high abundance on acidic soils. S. altissima occurred more often on well-drained soils, S. gigantea on moister soils with stable water levels over time, whereas $E$. graminifolia preferred clay-rich soils.

In Europe, S. altissima and S. gigantea are also considered as broad tolerant in terms of soil and climate conditions. They primarily invade abandoned fields and meadows as well as ruderal and disturbed habitats (Weber 2000; Weber and Jakobs 2005; Szymura and Szymura 2013; Bartha et al. 2014). Nonetheless, it appears that $S$. altissima prefers drier sites occurring along roadsides, railway lines and disturbed places around settlements, while $S$. gigantea is more frequent on river banks and moist areas often connected with river networks (Guzikowa and Maycock 1986; Weber 2001, 2011; Weber and Jakobs 2005). The presence of E. graminifolia was related to 
moist and wet habitats disturbed by humans (Guzikowa and Maycock 1986).

There is a lack of systematic measurements of primary environmental gradients that can be used for testing the hypothesis concerning the distribution of invasive goldenrods or for modelling their distribution. This is important because an increase of abundance and infilling available habitats within the species secondary range is occurring (Szymura and Szymura 2011; Bartha et al. 2014; Fenesi et al. 2015a, b). The relationship of a particular goldenrod species distribution with environmental conditions is unclear, particularly the recently observed tendency of $S$. gigantea to occupy drier habitats (Güsewell et al. 2005; Weber and Jakobs 2005; Láníková et al. 2009; Bartha et al. 2014).

The establishment of goldenrods from seedlings on abandoned lands occurs soon after the abandonment, whereas germination of seeds in undisturbed, wellestablished native vegetation is rather infrequent (Hartnett and Bazzaz 1985; Bartha et al. 2014; Fenesi et al. 2015b). After establishing at a new site, the subsequent spread of goldenrods is almost exclusively clonal via horizontal rhizomes, and the death of an established genet is a rare event (Meyer and Schmid 1999a, b). The age of single genets of S. altissima and S. canadensis has been reported to be 20-100 years (Whitham 1983; Carson and Root 2000). Consequently, goldenrods last for a long time during midsuccessional stages of vegetation (Cain 1990; Wise et al. 2006; Bornkamm 2007; Bartha et al. 2014; Fenesi et al. 2015a), and in such well-established stands, the recruitment of new individuals from seeds is rather unlikely (Hartnett and Bazzaz 1985; Meyer and Schmid 1999a). Therefore, it could be hypothesised that the pattern of goldenrod distribution is influenced by propagule pressure related to the invasion history; species that occur first may infill the available habitats and dominate the local vegetation. Since the number of goldenrod populations is increasing, the constant presence of their propagules increases the probability of successful colonisation when a gap occurs. Because goldenrods are similar with respect to the use of environmental resources and strongly affect the environment, the historical contingency caused by priority effect should restrict their distribution.

In this study, we assessed the relative roles of ecological niche differentiation, long-range dispersal limitation and historical contingency in determining the distribution of invasive goldenrods in Silesia, Central Europe. We tested the differences among species with respect to the following aspects: (a) habitat preferences of studied species, (b) composition of co-occurring vascular plant species, (c) climatic and topographical variables and (d) soil properties. To assess the potential role of priority effects and the subsequent density-dependent processes that lead to infilling by one species in a particular area, we modelled the spatial structure of plot locations, effects of distance from initial infestation sites and the environmental heterogeneity on goldenrod distribution. Finally, the quantitative effects of each of these factors on species distribution were separated.

\section{Materials and methods}

\section{Studied species}

We studied four alien goldenrod species (Solidago and Euthamia): S. gigantea Aiton, S. canadensis L., S. altissima L. and E. graminifolia (L.) Nutt. E. graminifolia is most commonly recognised in Europe as Solidago graminifolia (L.) Elliot; however, based on anatomical and DNA studies (Semple et al. 1981, 1984), the taxon should be classified to Euthamia Nutt. genus. The taxonomical problem concerned also considers $S$. canadensis and $S$. altissima as separate taxa. In several articles, these taxa are reported as two varieties of $S$. canadensis s.l.: var. canadensis and var. scabra (Guzikowa and Maycock 1986; Weber 1997; Weber and Schmid 1998). Among the primary traits that differ between $S$. altissima and $S$. canadensis, the length and arrangement of hair covering the stem and leaves and the shape and margins of the leaves (Weber 1997; Semple and Cook 2006), micro-morphological characteristics of leaf epidermis (Szymura and Wolski 2011) and rhizome systems (Schmid et al. 1988) have been described. In this study, the aforementioned species were separated into $S$. canadensis and $S$. altissima.

Goldenrods were introduced from North America in the eighteenth century and distributed to gardens in different parts of Europe (Hitchmough et al. 2004). After a short time, the goldenrods escaped from cultivation. At present, S. canadensis s.l. and $S$. gigantea are aggressive invaders that are widespread 
in Europe (Weber and Schmid 1998; Weber 2001; Schlaepfer et al. 2008). In contrast, E. graminifolia is present only at a few localities in Europe but can form dense, monospecific stands (Weber and Schmid 1998; Kompała-Bạba and Bąba 2006; Dajdok and Nowak 2007; Szymura and Szymura 2013). In Poland, the occurrence of $S$. gigantea was noted in 1853, $S$. canadensis s.l. in 1872 and E. graminifolia in 1885 (Guzikowa and Maycock 1986; Tokarska-Guzik 2003).

\section{Studied area and sampling plot design}

The fieldwork was performed in the Silesia region (Poland, Central Europe, sampled area approximately $32,000 \mathrm{~km}^{2}$, Fig. 1a). The studied area was mostly lowlands with a rather small portion of foothills and mountains (Fig. 1b); the land was mostly used for agriculture (approximately $64 \%$ ) and forestry (approximately $28 \%$ ). Within the study region (Fig. 1a), we established 309 plots, placed at the nodes of $10 \times 10 \mathrm{~km}$ regular grid. The altitudinal range of plots was from 50 to $1100 \mathrm{~m}$ above sea level; however, most of the plots were placed at an altitude below the $300 \mathrm{~m}$ a.s.l. The total annual precipitation varied between 533 and $858 \mathrm{~mm}$, and the average annual temperature varied between 3.5 and $9.2{ }^{\circ} \mathrm{C}$ (Hijmans et al. 2005). Each of the plots consisted of a buffer with a radius of $282 \mathrm{~m}$ (area $25 \mathrm{ha}$ ) within which the alien goldenrods were sampled. The centre of the buffer and the buffer extent were determined in the field using a GPS receiver. The land use/land cover (LULC) in the centre of the buffer was noted. If a population of alien goldenrods was found, the vegetation was sampled. The sampling plot was sized $10 \times 10 \mathrm{~m}$ (area $100 \mathrm{~m}^{2}$ ), and the cover of all vascular plants found was assessed using the Braun-Blanquet abundance scale. The nomenclature of plant species fallows to Mirek et al. (2002). The Polish vegetation database housed all the vegetation data (Kacki and Sliwinski 2012). Plots were established wherever Solidago first occurred, regardless of its abundance. If a few separated populations of a goldenrod species were found within the buffer, the stand placed nearest the buffer centre was sampled. If another species of alien goldenrods, forming a separate stand, was found, an additional sampling plot was established. By this way, in a particular buffer, no sampling plot (absence of goldenrods), a plot with a single goldenrod taxon, a plot with two or more goldenrod species or separate plots with different goldenrod taxa in each could be established. For each sampling plot, the LULC was noted, and the cover of trees and shrub canopy was visually assessed (canopy). The climatic conditions
Fig. 1 Studied region (panel a, dark grey) and pattern of historical (before 1939) infestation of particular goldenrod species (according to Guzikowa and Maycock 1986) in Silesia on the background of altitude and main rivers (panel b)

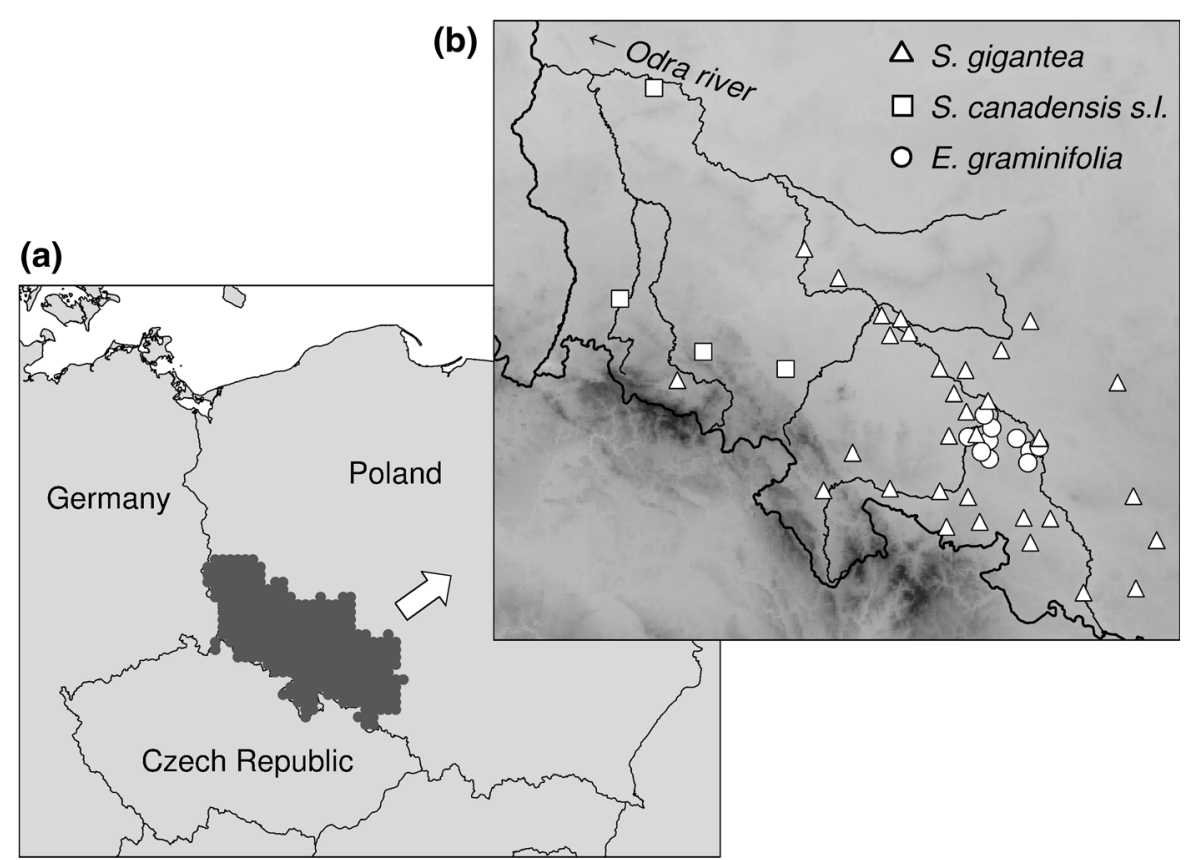


[average annual temperature (temp $\mathrm{p}_{\text {aver }}$ ), the maximal temperature of the warmest month $\left(\right.$ temp $\left._{\max }\right)$, the minimal temperature of the coldest month $\left(\right.$ temp $\left._{\min }\right)$ and the annual sum of precipitation (precipitation)] were determined from the climatic model of Hijmans et al. (2005). Using the digital elevation model (Jarvis et al. 2008), the altitude was defined and the topographic wetness index (TWI) was calculated.

Based on the LULC in the buffer centres and in the sampling plots, LULC was categorised. A total of 11 types of habitats were distinguished: (1) urban, industrial and transport areas (urbanised areas); (2) unpaved roads as footpaths, skidder trail in forests and sporadically used agricultural roads (unpaved roads); (3) drainage ditches and strips of land along paved roads (road verges); (4) habitat edges, e.g. forest/grassland ecotones; (5) various anthropogenic vegetation types, other than agriculture-allotments, orchards, gardens, parks (green areas); (6) meadows and pastures (grasslands); (7) forests and scrublands; (8) rivers, ditches, embankments or escarpments; (9) arable fields; (10) unmanaged strips of lands along fencing and other types of borders (property boundaries); and (11) abandoned lands. Sampling of the plots gave us knowledge about the frequency and distribution of each goldenrod species. For 78 sampling plots selected using a stratified-random method, topsoil samples were collected. As strata, species identity and geographical space were used. We tended to sample as much as possible of rare species ( $E$. graminifolia and $S$. canadensis) and to obtain spatially diversified In additionsamples of common species $(S$. altissima and $S$. gigantea). The selected 78 plots were the 'topsoil subset'. Soil samples from the top $20 \mathrm{~cm}$ were taken with a soil auger from four randomly chosen positions and mixed into one sample representing the plot. Then the subsamples collected from upper soil layer (approximately $20 \mathrm{~cm}$ ) were mixed into one sample representing the plot. In the laboratory, the samples were assessed for soil texture, $\mathrm{pH}$ of $\mathrm{H}_{2} \mathrm{O}$, carbon $(\mathrm{C})$, total nitrogen $(\mathrm{N})$, phosphorus $(\mathrm{P})$, potassium $(\mathrm{K})$, magnesium $(\mathrm{Mg})$ and calcium $(\mathrm{Ca})$ content.

\section{Statistical methods}

The percentage of different habitat types found in the buffer centres was calculated, including the percentage of habitats where particular goldenrod species occurred. Then, the difference between the proportion of goldenrods and those in the buffer centre with respect to particular species and habitat type was calculated. A negative value indicates that a particular goldenrod taxon was under-represented in a given habitat type, whereas a positive value indicated that it was over-represented. The significance of these differences compared to random was assessed with a $\chi^{2}$ test.

The tendency of the studied species to cluster or occur with a regular or random distribution was tested using Ripley's $K_{\mathrm{d}}$ function.

To verify whether the patches of vegetation invaded by particular goldenrod taxa differed with respect to vascular plant species composition, we analysed the similarity (ANOSIM) and, additionally, performed an ordination with non-metric multidimensional scaling (NMDS) using Bray-Curtis distance. As a grouping factor in the ANOSIM, the occurrence of particular goldenrod taxa was used; in the case of plots invaded by multiple goldenrod species, we classified it as a 'mixture'. Because the results of NMDS ordination would be under the strong influence of the presence of particular goldenrod taxa, they were excluded from the analysis.

The significance of differences in environmental traits across species was tested using permutation and Kruskal-Wallis analysis of variance on ranks with a Nemenyi-Damico-Wolfe-Dunn post hoc test (Hollander and Wolfe 1999; Hothorn et al. 2013).

For all plots, the shortest distances to the initial invasion location in Silesia were calculated. Data regarding the initial invasion (distribution before WW II) were derived from Guzikowa and Maycock (1986; Fig. 1b). As the authors of that article did not distinguish S. altissima, we calculated the distances to the locations of initial infestations by E. graminifolia (minEut), S. gigantea (minGig) and S. canadensis sensu lato (minCan).

For modelling goldenrod spatial distributions, we used the principal coordinate analysis of neighbour matrices (PCNMs; Borcard and Legendre 2002; Dray et al. 2006). The geographical coordinates of the plots were used to compute PCNM, from which vectors that represented statistically significant positive spatial correlations were selected, using Moran's I (Borcard and Legendre 2002; Borcard et al. 2004). The PCNM vectors were calculated independently for the entire dataset $(N=232)$ as well as for the topsoil subset $(N=78)$. 
All environmental data, distances to initial invasion sites and the PCNM vectors were used as explanatory variables in a canonical correspondence analysis (CCA) of alien goldenrod distribution using presence/absence data. Two independent analyses were performed. First, using the all predictor variables for the entire dataset. The second analysis used the canopy, topsoil properties, the shortest distances and PCNM vectors for the topsoil subset. Within the analysis, models exclusively for environmental data (environment) were separately constructed, which were used as the explanatory variables solely for the shortest distances (distance) and for the spatial data alone (space) as explanatory variables. In these models, using forward selection procedures, the variables that significantly shaped alien goldenrod distribution were selected. Finally, combined models, including significant environmental, spatial and distance variables, were constructed. For these combined goldenrod distribution models, variance partitioning (Borcard et al. 1992; Peres-Neto et al. 2006) was used to quantify the amount of variation explained by the three different groups of factors (space, environment and distance). In addition, correlations between the site scores obtained in the CCA models with space as explanatory variables on one hand and species data, environment and the distance group of variables on the other hand were checked to determine which species and/or which variables were associated with the spatial structures of goldenrod population. The significance of the correlations was checked using the Monte Carlo permutation method (Hothorn et al. 2013).

Statistical analyses were performed using 'vegan' and 'coin' packages in R environment (Oksanen et al. 2008; Hothorn et al. 2013) and PASSAGE (Rosenberg and Anderson 2011) software for spatial analysis.

\section{Results}

Among the analysed 309 buffers, 232 sampling plots were established. Monospecific stands of $S$. gigantea $(N=92,40 \%)$ or $S$. altissima $(N=88,38 \%)$ were found in most of the plots. In contrast, plots with a mixture of these two species $(N=23,10 \%)$ rarely occurred. The two remaining species, $S$. canadensis $(N=21)$ and $E$. graminifolia $(N=9)$, were much rarer and mostly occurred in stands along with other goldenrod species (Fig. 2).
Solidago canadensis occurred most often as a few ramets in the $10 \times 10 \mathrm{~m}$ plots (' + ' according to the Braun-Blanquet scale), $S$. altissima and $S$. gigantea mostly covered up to $5 \%$ of the plot (' 1 ' in B-B scale), while E. graminifolia covers most often 5-25\% of the plot area ('2' in B-B scale). However, $S$. altissima and $S$. gigantea in some plots can cover more than $50 \%$ of the plot (' 4 ' and ' 5 ' according to BB scale, Online Resource A).

The distributions of $S$. gigantea and S. altissima were clustered (values of Ripley's $K_{\mathrm{d}}$ function above random ranges, Fig. 3), and their ranges did not overlap entirely within the studied region. S. canadensis was randomly distributed throughout the region. The range of E. graminifolia was restricted to one area, but within that range, its distribution was random.

Goldenrods were most often found on abandoned lands and road verges. The number of plots for particular species and habitat types is listed in Online Resource B. All species avoided arable fields and urbanised areas but were over-represented on road verges (Fig. 4). We observed differences between the percentage of habitats invaded by E. graminifolia and other species. E. graminifolia was over-represented on unpaved roads and, in contrast to other species, underrepresented on abandoned lands but did not significantly avoid forests and scrublands.

The most frequent species co-occurring with the goldenrods were Cirsium arvense (57.3\%), Artemisia vulgaris $(56.9 \%)$, Urtica dioica $(50.0 \%)$, Achillea

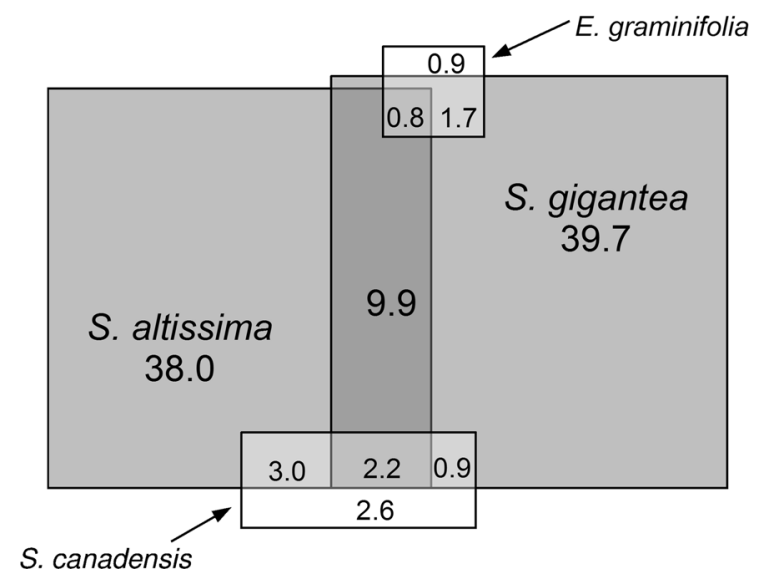

Fig. 2 Percentage of plots with particular goldenrod species growing in monocultures or mixtures with other goldenrod taxa. In total, 232 plots were sampled with one or more goldenrod species on each 
Fig. 3 Maps of the studied species distribution (grey dots) and values of Ripley's $K_{\mathrm{d}}$ function of different spatial extents. The grey area on Ripley's $K_{\mathrm{d}}$ graphs shows ranges for random distribution. The crosses on the maps denote the centres of the studied buffers
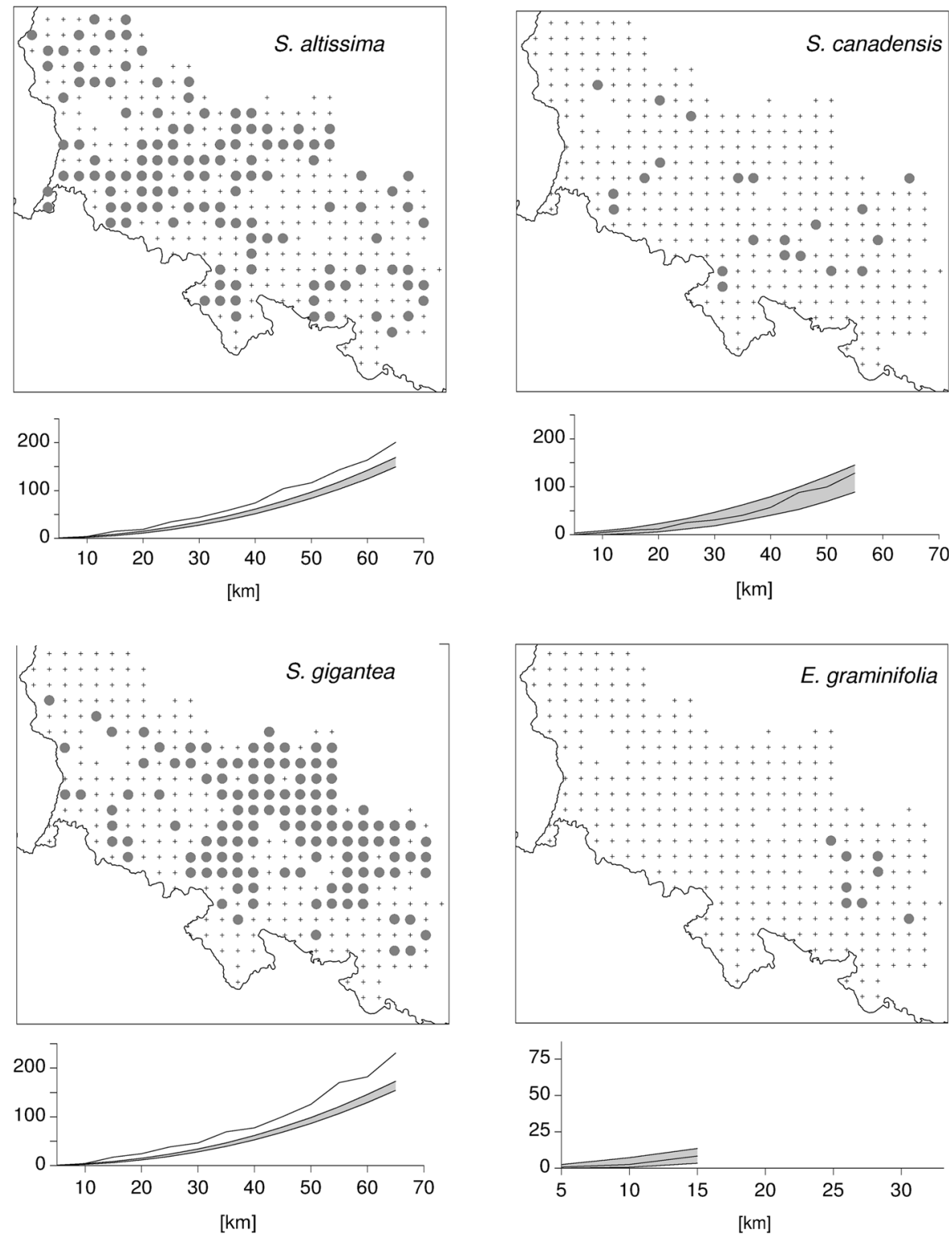

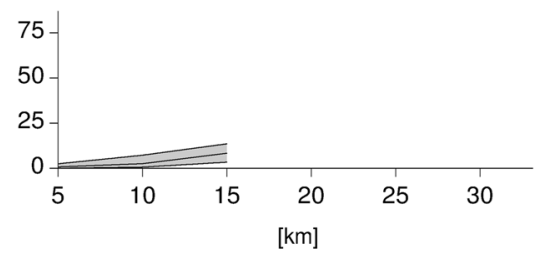

millefolium $(49.1 \%)$ and Dactylis glomerata $(43.1 \%)$. All of the species found in the sample plots are listed in Online Resource C. The results of ANOSIM showed that there were no significant differences $(R=-0.006, p=0.660)$ between the plots invaded by different goldenrod species with respect to vascular plant species composition. The NMDS ordination of plots invaded by particular goldenrod taxa (Fig. 5, upper panel) was consistent with the results of ANOSIM; that is, the goldenrod species did not have any tendency to form clusters with particular species composition. The exception was the tendency of $E$. graminifolia to concentrate on the right side of the graph with forest species. The ordination of species (Fig. 5, lower panel) suggests that the first axis is related to the gradient from frequently disturbed habitats (left wing of the graph, arable weeds and annual or biennial ruderal species such as Tripleurospermum inodorum, Conyza canadensis and Setaria viridis) through meadows/grassland vegetation (centre of the graph, Arrhenatherum elatius, D. glomerata and Lolium 


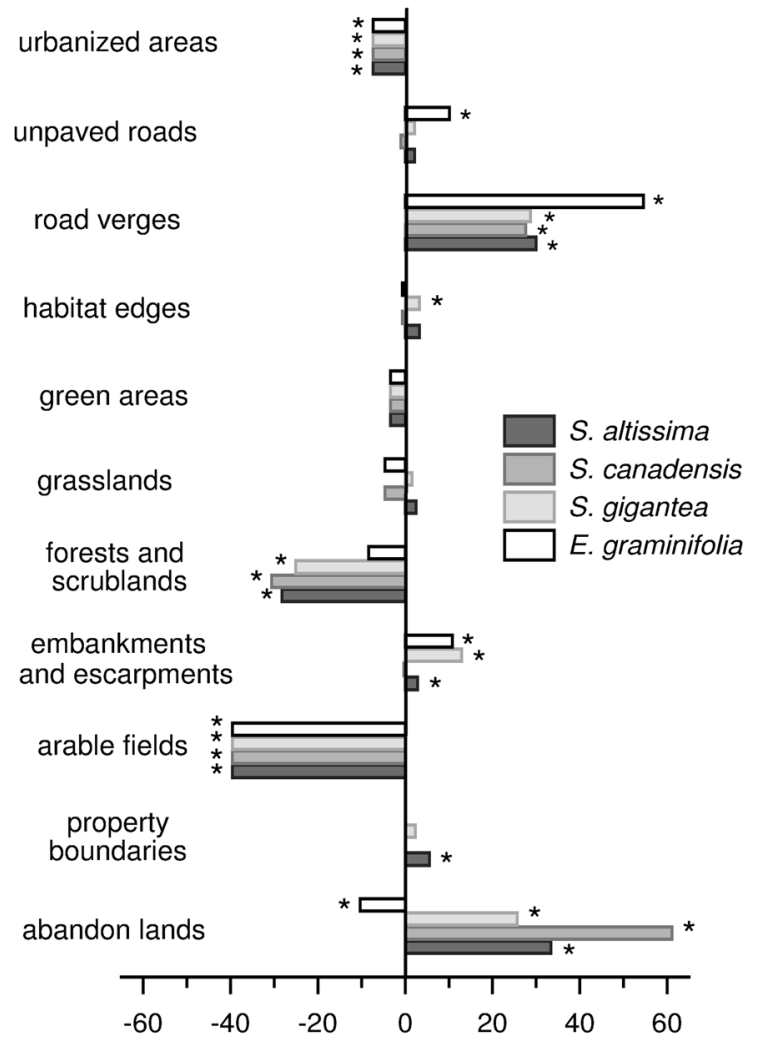

underrepresentation [\%] overrepresentation

Fig. 4 Differences between the percentages of habitat types calculated for the goldenrods and the buffer centres. The positive values reveal over-representation of goldenrod species in the particular type, while the negative values show underrepresentation. The asterisks show statistical significance

perenne) up to relatively undisturbed forest vegetation (right wing, tree and shrub species such as Sorbus aucuparia, Corylus avellana and Quercus robur). The second axis can be interpreted as decreasing moisture gradient from moderate (upper part of the graph, Oxalis acetosella, Pinus sylvestris and Equisetum pratense) to wet habitats (lower part, Phragmites australis, Stellaria media and Filipendula ulmaria).

Goldenrods occurred in a wide range of soils with respect to $\mathrm{pH}$, nutrient content and texture. We found significant differences between taxa with respect to environmental variables (Table 1). E. graminifolia occurred in more over-shaded plots than S. altissima and $S$. canadensis; however, the latter species were also sporadically found under canopy cover. We also found differences between $E$. graminifolia and the remaining species with respect to the average
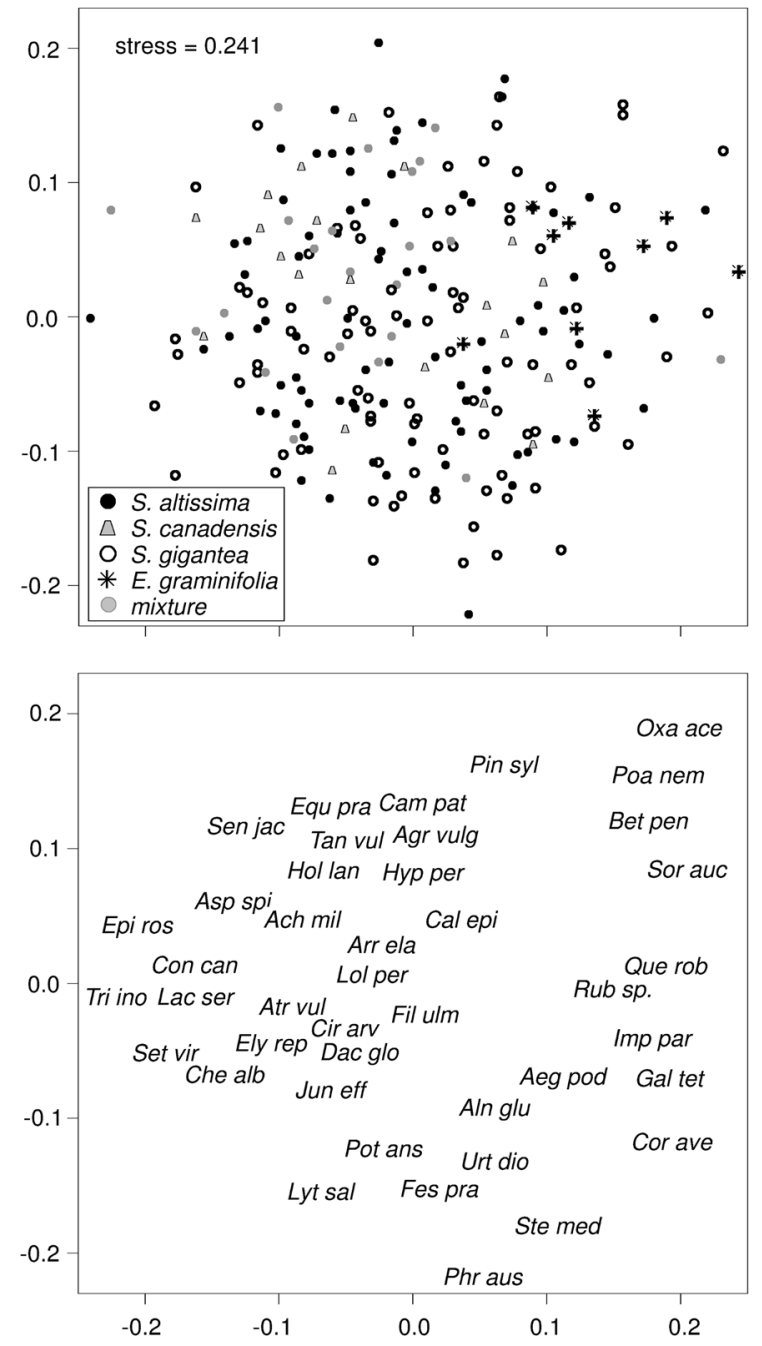

Fig. 5 Results of NMDS ordination. The upper panel shows the ordination of the plots. Because of the low number of plots with $E$. graminifolia (asterisks) and S. canadensis (grey trapeze) in these two groups, plots where these two species occur in combination with $S$. altissima and/or $S$. gigantea were also included. The group mixture (grey dots) consists of plots with a mixture of $S$. gigantea and $S$. altissima, exclusively. The lower panel shows the ordination of the species. For legibility, only the species, distribution of which was best explained by the ordination model, and/or the most frequent species were shown. The species labels consist of the first three letters of genus and species Latin names. The full names are given in Online Resource C

precipitation (S. gigantea) and minimum temperature ( $S$. altissima and $S$. canadensis); nonetheless, the ranges of these climatic variables overlapped among species. Analysis of the topsoil subset also revealed differences of E. graminifolia in lower $\mathrm{K}$ and $\mathrm{Mg}$ contents and a tendency to occur on more sandy soils 
Table 1 The average \pm standard deviation and range (in parenthesis) of environmental variables for each goldenrod species, the shortest distance to the initial infestation location (distance) and the results of statistical tests $\left(\chi^{2}, p\right)$

\begin{tabular}{|c|c|c|c|c|c|}
\hline & S. altissima & S. canadensis & S. gigantea & E. graminifolia & \\
\hline \multicolumn{6}{|l|}{ Entire dataset } \\
\hline$N$ observations & 127 & 21 & 129 & 9 & \\
\hline Canopy & $\begin{array}{l}11.7^{\mathrm{b}} \pm 21.4 \\
(0.0 \text { to } 100.0)\end{array}$ & $\begin{array}{l}10.2^{\mathrm{b}} \pm 20.3 \\
(0.0 \text { to } 70.0)\end{array}$ & $\begin{array}{l}17.2^{\mathrm{a}, \mathrm{b}} \pm 27.7 \\
(0.0 \text { to } 100.0)\end{array}$ & $\begin{array}{l}33.3^{\mathrm{a}} \pm 28.2 \\
(0.0 \text { to } 80.0)\end{array}$ & $\begin{array}{l}\chi^{2}=9.166 \\
p=0.024\end{array}$ \\
\hline Precipitation & $\begin{array}{l}590.8^{\mathrm{a}, \mathrm{b}} \pm 38.7 \\
(535.0 \text { to } 737.0)\end{array}$ & $\begin{array}{l}592.0^{\mathrm{a}} \pm 32.3 \\
(556.0 \text { to } 671.0)\end{array}$ & $\begin{array}{l}580.7^{\mathrm{b}} \pm 34.8 \\
(533.0 \text { to } 675.0)\end{array}$ & $\begin{array}{l}600.7^{\mathrm{a}} \pm 24.5 \\
(567.0 \text { to } 648.0)\end{array}$ & $\begin{array}{l}\chi^{2}=9.736 \\
p=0.017\end{array}$ \\
\hline TWI & $\begin{array}{l}19.9 \pm 2.3 \\
(9.0 \text { to } 22.7)\end{array}$ & $\begin{array}{l}19.5 \pm 2.6 \\
(11.2 \text { to } 22.7)\end{array}$ & $\begin{array}{l}19.8 \pm 2.0 \\
(12.2 \text { to } 22.9)\end{array}$ & $\begin{array}{l}21.3 \pm 0.8 \\
(20.2 \text { to } 22.5)\end{array}$ & $\begin{array}{l}\chi^{2}=7.611 \\
p=0.051\end{array}$ \\
\hline Altitude & $\begin{array}{l}204.9 \pm 106.3 \\
(53.0 \text { to } 674.0)\end{array}$ & $\begin{array}{l}218.3 \pm 95.8 \\
(98.0 \text { to } 424.0)\end{array}$ & $\begin{array}{l}185.5 \pm 83.3 \\
(86.0 \text { to } 487.0)\end{array}$ & $\begin{array}{l}181.0 \pm 33.6 \\
(147.0 \text { to } 246.0)\end{array}$ & $\begin{array}{l}\chi^{2}=4.723 \\
p=0.198\end{array}$ \\
\hline Temp ${ }_{\text {aver }}$ & $\begin{array}{l}8.1 \pm 0.7 \\
(5.4 \text { to } 9.2)\end{array}$ & $\begin{array}{l}8.0 \pm 0.6 \\
(6.7 \text { to } 8.9)\end{array}$ & $\begin{array}{l}8.1 \pm 0.5 \\
(6.4 \text { to } 8.9)\end{array}$ & $\begin{array}{l}8.3 \pm 0.1 \\
(8.1 \text { to } 8.4)\end{array}$ & $\begin{array}{l}\chi^{2}=2.358 \\
p=0.514\end{array}$ \\
\hline Temp $\max$ & $\begin{array}{l}23.1 \pm 0.9 \\
(19.2 \text { to } 24.5)\end{array}$ & $\begin{array}{l}23.0 \pm 0.8 \\
(21.3 \text { to } 23.8)\end{array}$ & $\begin{array}{l}23.2 \pm 0.6 \\
(20.9 \text { to } 24.2)\end{array}$ & $\begin{array}{l}23.3 \pm 0.2 \\
(23.1 \text { to } 23.5)\end{array}$ & $\begin{array}{l}\chi^{2}=1.197 \\
p=0.760\end{array}$ \\
\hline Temp $_{\text {min }}$ & $\begin{array}{l}-5.7^{\mathrm{a}} \pm 1.0 \\
(-8.3 \text { to }-4.0)\end{array}$ & $\begin{array}{l}-5.7^{\mathrm{a}} \pm 0.8 \\
(-7.2 \text { to }-4.3)\end{array}$ & $\begin{array}{l}-5.6^{\mathrm{a}, \mathrm{b}} \pm 0.7 \\
(-7.7 \text { to }-4.0)\end{array}$ & $\begin{array}{l}-5.0^{\mathrm{b}} \pm 0.2 \\
(-5.4 \text { to }-4.8)\end{array}$ & $\begin{array}{l}\chi^{2}=9.729 \\
p=0.019\end{array}$ \\
\hline Distance* & $\begin{array}{l}53.2^{\mathrm{a}} \pm 37.2 \\
(0.2 \text { to } 152.2)\end{array}$ & & $\begin{array}{l}20.8^{\mathrm{b}} \pm 16.9 \\
(2.2 \text { to } 108.5)\end{array}$ & $\begin{array}{l}11.9^{b} \pm 6.5 \\
(2.2 \text { to } 21.2)\end{array}$ & $\begin{array}{l}\chi^{2}=80.744 \\
p=0.000\end{array}$ \\
\hline \multicolumn{6}{|l|}{ Topsoil subset } \\
\hline$N$ observations & 46 & 18 & 43 & 8 & \\
\hline Canopy & $\begin{array}{l}12.1 \pm 21.1 \\
(0.0 \text { to } 80.0)\end{array}$ & $\begin{array}{l}10.8 \pm 22.0 \\
(0.0 \text { to } 70.0)\end{array}$ & $\begin{array}{l}12.2 \pm 21.4 \\
(0.0 \text { to } 80.0)\end{array}$ & $\begin{array}{l}31.9 \pm 29.8 \\
(0.0 \text { to } 80.0)\end{array}$ & $\begin{array}{l}\chi^{2}=7.145 \\
p=0.066\end{array}$ \\
\hline $\mathrm{pH}$ & $\begin{array}{l}5.9 \pm 0.8 \\
(4.3 \text { to } 7.9)\end{array}$ & $\begin{array}{l}5.8 \pm 0.9 \\
(4.3 \text { to } 8.0)\end{array}$ & $\begin{array}{l}5.8 \pm 0.9 \\
(4.3 \text { to } 8.0)\end{array}$ & $\begin{array}{l}5.7 \pm 1.1 \\
(4.4 \text { to } 7.1)\end{array}$ & $\begin{array}{l}\chi^{2}=0.502 \\
p=0.922\end{array}$ \\
\hline $\mathrm{C}$ & $\begin{array}{l}3.3 \pm 3.4 \\
(0.3 \text { to } 20.0)\end{array}$ & $\begin{array}{l}2.1 \pm 1.0 \\
(0.6 \text { to } 4.1)\end{array}$ & $\begin{array}{l}3.7 \pm 4.0 \\
(0.6 \text { to } 20.3)\end{array}$ & $\begin{array}{l}4.2 \pm 3.9 \\
(1.3 \text { to } 13.6)\end{array}$ & $\begin{array}{l}\chi^{2}=3.769 \\
p=0.296\end{array}$ \\
\hline $\mathrm{N}$ & $\begin{array}{l}1.6 \pm 1.3 \\
(0.3 \text { to } 9.1)\end{array}$ & $\begin{array}{l}1.2 \pm 0.4 \\
(0.7 \text { to } 1.8)\end{array}$ & $\begin{array}{l}1.5 \pm 0.9 \\
(0.6 \text { to } 4.7)\end{array}$ & $\begin{array}{l}1.3 \pm 0.7 \\
(0.6 \text { to } 2.9)\end{array}$ & $\begin{array}{l}\chi^{2}=1.799 \\
p=0.622\end{array}$ \\
\hline $\mathrm{C} / \mathrm{N}$ & $\begin{array}{l}2.0^{\mathrm{a}, \mathrm{b}} \pm 0.7 \\
(0.9 \text { to } 4.7)\end{array}$ & $\begin{array}{l}1.7^{\mathrm{b}} \pm 0.5 \\
(0.9 \text { to } 2.7)\end{array}$ & $\begin{array}{l}2.1^{\mathrm{a}, \mathrm{b}} \pm 0.9 \\
(0.9 \text { to } 5.3)\end{array}$ & $\begin{array}{l}2.9^{\mathrm{a}} \pm 1.1 \\
(1.5 \text { to } 4.8)\end{array}$ & $\begin{array}{l}\chi^{2}=10.485 \\
p=0.014\end{array}$ \\
\hline $\mathrm{P}$ & $\begin{array}{l}47.7 \pm 58.7 \\
(3.8 \text { to } 279.5)\end{array}$ & $\begin{array}{l}38.7 \pm 26.6 \\
(6.2 \text { to } 102.8)\end{array}$ & $\begin{array}{l}47.9 \pm 53.8 \\
(3.6 \text { to } 211.2)\end{array}$ & $\begin{array}{l}13.4 \pm 8.4 \\
(5.9 \text { to } 29.5)\end{array}$ & $\begin{array}{l}\chi^{2}=7.036 \\
p=0.069\end{array}$ \\
\hline $\mathrm{K}$ & $\begin{array}{l}155.2^{\mathrm{a}} \pm 122.0 \\
(20.0 \text { to } 545.0)\end{array}$ & $\begin{array}{l}141.4^{\mathrm{a}, \mathrm{b}} \pm 96.7 \\
(20.0 \text { to } 355.0)\end{array}$ & $\begin{array}{l}120.2^{\mathrm{a}, \mathrm{b}} \pm 111.5 \\
(5.0 \text { to } 520.0)\end{array}$ & $\begin{array}{l}41.9^{\mathrm{b}} \pm 26.2 \\
(20.0 \text { to } 95.0)\end{array}$ & $\begin{array}{l}\chi^{2}=11.139 \\
p=0.011\end{array}$ \\
\hline $\mathrm{Mg}$ & $\begin{array}{l}98.2^{\mathrm{a}} \pm 55.7 \\
(22.2 \text { to } 234.8)\end{array}$ & $\begin{array}{l}84.0^{\mathrm{a}, \mathrm{b}} \pm 47.4 \\
(25.4 \text { to } 170.0)\end{array}$ & $\begin{array}{l}80.9^{\mathrm{a}, \mathrm{b}} \pm 64.5 \\
(17.1 \text { to } 380.6)\end{array}$ & $\begin{array}{l}50.7^{\mathrm{b}} \pm 32.2 \\
(22.2 \text { to } 115.0)\end{array}$ & $\begin{array}{l}\chi^{2}=8.428 \\
p=0.032\end{array}$ \\
\hline $\mathrm{Ca}$ & $\begin{array}{l}710.1 \pm 883.5 \\
(147.0 \text { to } 4206.0)\end{array}$ & $\begin{array}{l}760.9 \pm 1135.2 \\
(170.0 \text { to } 4206.0)\end{array}$ & $\begin{array}{l}709.5 \pm 837.1 \\
\text { (18.0 to } 3372.0)\end{array}$ & $\begin{array}{l}1351.0 \pm 1664.1 \\
(18.0 \text { to } 4206.0)\end{array}$ & $\begin{array}{l}\chi^{2}=0.356 \\
p=0.953\end{array}$ \\
\hline Sand & $\begin{array}{l}55.4^{\mathrm{c}} \pm 21.2 \\
(21.0 \text { to } 90.0)\end{array}$ & $\begin{array}{l}55.2^{\mathrm{b}, \mathrm{c}} \pm 22.4 \\
(27.0 \text { to } 90.0)\end{array}$ & $\begin{array}{l}66.8^{\mathrm{a}, \mathrm{b}} \pm 18.7 \\
(27.0 \text { to } 91.0)\end{array}$ & $\begin{array}{l}81.3^{\mathrm{a}} \pm 5.2 \\
(73.0 \text { to } 88.0)\end{array}$ & $\begin{array}{l}\chi^{2}=14.434 \\
p=0.001\end{array}$ \\
\hline Silt & $\begin{array}{l}41.3^{\mathrm{a}} \pm 19.4 \\
(10.0 \text { to } 73.0)\end{array}$ & $\begin{array}{l}41.8^{\mathrm{a}, \mathrm{b}} \pm 20.6 \\
(10.0 \text { to } 68.0)\end{array}$ & $\begin{array}{l}31.1^{\mathrm{b}, \mathrm{c}} \pm 17.0 \\
(9.0 \text { to } 68.0)\end{array}$ & $\begin{array}{l}17.6^{\mathrm{c}} \pm 5.0 \\
(11.0 \text { to } 25.0)\end{array}$ & $\begin{array}{l}\chi^{2}=14.252 \\
p=0.002\end{array}$ \\
\hline Clay & $\begin{array}{l}3.3^{\mathrm{a}} \pm 2.3 \\
(0.0 \text { to } 12.0)\end{array}$ & $\begin{array}{l}2.9^{\mathrm{a}, \mathrm{b}} \pm 2.0 \\
(0.0 \text { to } 6.0)\end{array}$ & $\begin{array}{l}2.1^{\mathrm{b}, \mathrm{c}} \pm 1.8 \\
(0.0 \text { to } 8.0)\end{array}$ & $\begin{array}{l}1.1^{\mathrm{c}} \pm 0.4 \\
(1.0 \text { to } 2.0)\end{array}$ & $\begin{array}{l}\chi^{2}=13.386 \\
p=0.002\end{array}$ \\
\hline
\end{tabular}


Table 1 continued

\begin{tabular}{llllll}
\hline & S. altissima & S. canadensis & S. gigantea & E. graminifolia \\
\hline Precipitation & $595.7 \pm 41.9$ & $596.0 \pm 33.1$ & $582.7 \pm 30.9$ & $601.5 \pm 26.0$ & $\chi^{2}=4.484$ \\
& $(540.0$ to 720.0$)$ & $(556.0$ to 671.0$)$ & $(536.0$ to 671.0$)$ & $(567.0$ to 648.0$)$ & $p=0.215$ \\
Distance* & $55.2^{\mathrm{a}} \pm 39.6$ & & $20.4^{\mathrm{b}} \pm 17.7$ & $13.3^{\mathrm{b}} \pm 8.9 \quad$ & $\chi^{\mathbf{2}=\mathbf{3 1 . 5 9 5}}$ \\
& $(7.4$ to 152.2$)$ & & $(2.282 .8)$ & $(2.3$ to 25.9$) \quad(\mathbf{p})$ \\
\hline
\end{tabular}

Asterisk indicates the Distance was calculated for S. canadensis s.I.

Bold values indicate statistically significant results at $p$ level 0.05

The different superscript letters denote significant differences between pairs of taxa. The sum of observations for particular taxa for the entire dataset and topsoil subset is not equal to the number of studied plots since two or more species can occur on some plots

compared to $S$. altissima as well as on soils with a higher $\mathrm{C} / \mathrm{N}$ ratio compared to $S$. canadensis (Table 1).

The results of CCA of the entire dataset and the topsoil subset are presented in Table 2. The CCA model results, developed for the entire dataset, using the environmental variables showed that the distribution of goldenrods was significantly shaped by precipitation and canopy. Their distribution was also significantly influenced by the shortest distance to initial infestation sites (distance) of E. graminifolia (minEut) and S. canadensis (minCan). It was found that the distance explained more variation than the environment (Table 2). However, the space represented by PCNM vectors better described the variability of goldenrod distribution (Table 2). In particular, the first CCA axis adequately modelled the distribution of E. graminifolia (Fig. 6, upper panel, high positive scores), while the second CCA axis well represented the contrast between the plots invaded by $S$. gigantea (high positive scores) and $S$. altissima (moderate and negative scores). The values of PCNM vectors that significantly shaped goldenrod distribution plotted against geographical coordinates

Table 2 Results of canonical correspondence analysis (CCA) $\left(R^{2}, F\right.$ and $\left.p\right)$ of the entire dataset and topsoil subset

\begin{tabular}{llrl}
\hline & $R^{2}$ & $F$ & $p$ \\
\hline Entire dataset & & & \\
Environment & 0.031 & 6.531 & 0.005 \\
Distance & 0.081 & 10.053 & 0.005 \\
Space & 0.169 & 6.531 & 0.005 \\
Topsoil subset & & & \\
Environment & 0.161 & 4.152 & 0.005 \\
Distance & 0.121 & 3.402 & 0.005 \\
Space & 0.208 & 4.786 & 0.005 \\
\hline
\end{tabular}

are presented in Online Resource D. It was found that not only the distribution of all the studied goldenrod species but also the canopy, precipitation and the distance (minCan, minEut) were correlated with the CCA axis calculated on the basis of PCNM vectors (Table 3). This implies that the environmental variables were not randomly distributed throughout the studied region but spatially structured and that the PCNM variables also well reflected the distance. The combined model that joins environment, distance and space variables significantly explained approximately $19.6 \%$ of goldenrod distribution variability (Fig. 6, lower panel). The combined model explained the distribution variabilities of $32.5 \%$ of E. graminifolia, $23.5 \%$ of S. altissima, $15.8 \%$ of S. gigantea and $5.6 \%$ of $S$. canadensis. The procedure of variation partitioning showed that space explains far more variation than the environment. The fraction of variation explained by pure distance was relatively less; however, the high amount of explained variation was shared with space. The fraction of explained variation shared by these three components concurrently was relatively small (Fig. 6, lower panel). The first ordination axis, explaining most of the variation, well modelled the distribution of E. graminifolia. The second axis reflected the differences between $S$. altissima and S. gigantea (Fig. 6, lower panel).

The ordination of the topsoil subset showed that goldenrod distributions were significantly shaped by $\mathrm{C} / \mathrm{N}$ ratio and $\mathrm{Mg}$ and the percentage of silt in the soil among the environmental components. The shortest distances to initial infestation sites (distance) of $E$. graminifolia (minEut) and S. canadensis (minCan), as well as the four PCNM vectors, also significantly influenced goldenrod distribution, when the distance and space group of factors were analysed (Table 2). The distribution of S. gigantea, S. altissima and $E$. 

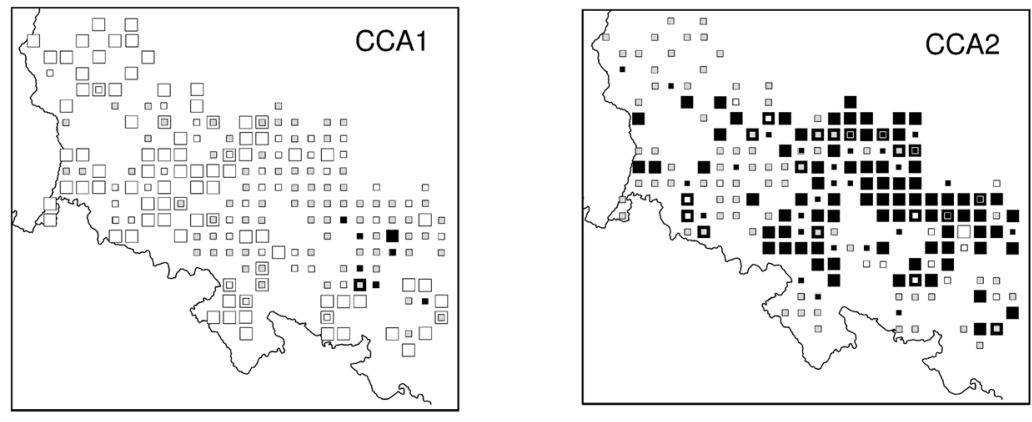

high negative site score

high positive site score

environment

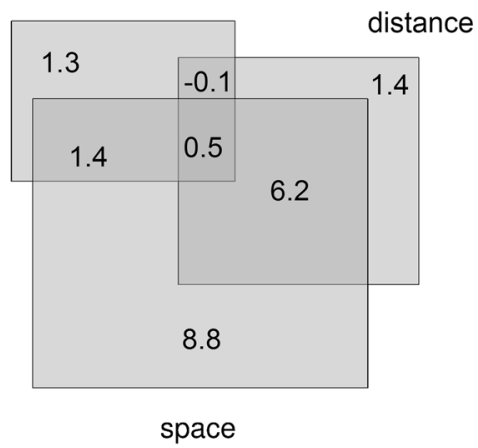

constrained $=19.6 \%$ unconstrained $=80.4$

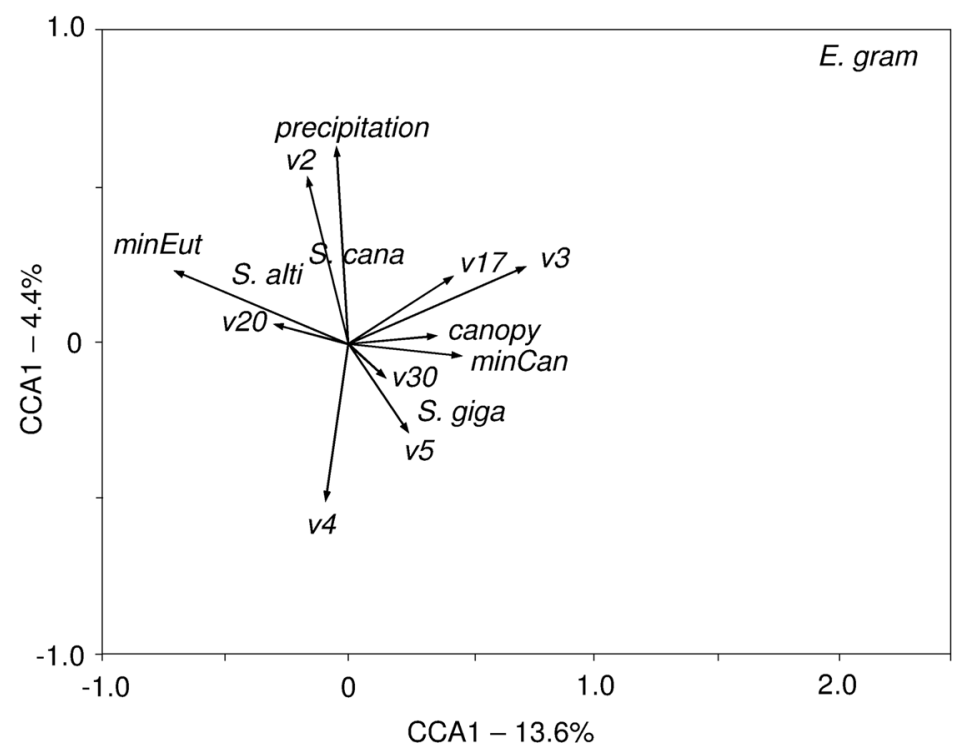

partitioning results on the left and the CCA biplot on the right. minCan the shortest distance to the initial infestation location from $S$. canadensis s.l. plots; minEut the shortest distance to the initial infestation location from E. graminifolia plots, E. gram E. graminifolia, S. alti S. altissima, S. cana S. canadensis, S. giga $S$. gigantea, V2-V30 PCNM vectors

The first ordination axis again reflected the contrast between the sites invaded by E. graminifolia and the remaining species, while the second axis represented the differentiation between S. altissima and S. gigantea (Fig. 7, lower panel). The details of the topsoil subset analysis are shown in the Online Resource E.

\section{Discussion}

Solidago altissima and S. gigantea

The frequently observed patchy distributions of invasive plant species can result from both dispersal $19.9 \%$ of $S$. gigantea and $10.3 \%$ of $S$. canadensis. 
Table 3 Correlations between species data, environmental variables and the shortest distances significantly shaping species distribution, from one side, and canonical axes derived from CCA analysis with PCNM vectors as explanatory variables, on the other

\begin{tabular}{|c|c|c|c|c|}
\hline \multirow[t]{2}{*}{ Components } & \multicolumn{2}{|l|}{ Entire dataset } & \multicolumn{2}{|l|}{ Topsoil subset } \\
\hline & CCA1 & $\mathrm{CCA} 2$ & CCA1 & $\mathrm{CCA} 2$ \\
\hline S. altissima & $\begin{array}{l}Z=-13.332 \\
p<0.001\end{array}$ & $\begin{array}{l}Z=-11.001 \\
p<0.001\end{array}$ & $\begin{array}{l}Z=-6.335 \\
p<0.001\end{array}$ & $\begin{array}{l}Z=-5.739 \\
p<0.001\end{array}$ \\
\hline S. canadensis & n.s. & $\begin{array}{l}Z=-5.353 \\
p<0.001\end{array}$ & $\begin{array}{l}Z=-1.263 \\
p=0.206\end{array}$ & $\begin{array}{l}Z=0.4496 \\
p=0.653\end{array}$ \\
\hline S. gigantea & $\begin{array}{l}Z=12.825 \\
p<0.001\end{array}$ & $\begin{array}{l}Z=12.733 \\
p<0.001\end{array}$ & $\begin{array}{l}Z=6.876 \\
p<0.001\end{array}$ & $\begin{array}{l}Z=-7.104 \\
p<0.001\end{array}$ \\
\hline E. graminifolia & $\begin{array}{l}Z=5.413 \\
p<0.001\end{array}$ & $\begin{array}{l}Z=-5.251 \\
p<0.001\end{array}$ & $\begin{array}{l}Z=4.725 \\
p<0.001\end{array}$ & $\begin{array}{l}Z=2.498 \\
p=0.012\end{array}$ \\
\hline Precipitation & n.s. & $\begin{array}{l}Z=-3.2814 \\
p=0.001\end{array}$ & - & - \\
\hline Canopy & $\begin{array}{l}Z=2.182 \\
p=0.029\end{array}$ & n.s. & - & - \\
\hline $\mathrm{C} / \mathrm{N}$ & - & - & $\begin{array}{l}Z=1.8002 \\
p=0.072\end{array}$ & $\begin{array}{l}Z=0.654 \\
p=0.513\end{array}$ \\
\hline $\mathrm{Mg}$ & - & - & $\begin{array}{l}Z=-2.688 \\
p=0.007\end{array}$ & $\begin{array}{l}Z=0.968 \\
p=0.333\end{array}$ \\
\hline Silt & - & - & $\begin{array}{l}Z=-3.824 \\
p=0.001\end{array}$ & $\begin{array}{l}Z=1.614 \\
p=0.106\end{array}$ \\
\hline minEut & $\begin{array}{l}Z=-6.337 \\
p<0.001\end{array}$ & $\begin{array}{l}Z=-2.508 \\
p=0.012\end{array}$ & $\begin{array}{l}Z=-4.633 \\
p<0.001\end{array}$ & $\begin{array}{l}Z=1.672 \\
p=0.094\end{array}$ \\
\hline $\operatorname{minCan}$ & $\begin{array}{l}Z=4.636 \\
p<0.001\end{array}$ & $\begin{array}{l}Z=1.767 \\
p=0.077\end{array}$ & $\begin{array}{l}Z=3.954 \\
p<0.001\end{array}$ & $\begin{aligned} Z & =-1.717 \\
p & =0.086\end{aligned}$ \\
\hline
\end{tabular}

limitation and lack of suitable habitats (Warren et al. 2013). Local dispersal, which leads to infilling gaps within the invaded range, drives the landscape coverage of the invader and, usually, its environmental impact (Wangen and Webster 2006; Miller and Matlack 2010; Warren et al. 2013; Bartha et al. 2014). Because of this, the observation of aggregated patterning without other analysis does not provide an explanation of the ecological processes and limitations, which determine the observed distribution (Warren et al. 2013).

In contrast to previous analyses regarding the differentiation of ecological niches between $S$. altissima and $S$. gigantea, our study reveals little differentiation of climatic and soil conditions, and none in the invaded habitats. Despite the fact that in the native range, $S$. altissima is considered as preferring drier sites than $S$. gigantea (Weber and Jakobs 2005; Weber 2000), we did not find such environmental preferences in the studied region based both on TWI and plant species composition. A factor essential for successful invasion is competition with resident vegetation (Levine et al. 2003; Vilá and Weiner 2004; van Kleunen et al. 2010; Gioria and Osborne 2014; Kuebbing and Nuñez 2015). Based on the results, there is no reason to assume that native vegetation in areas invaded by these two taxa differs. The results of ANOSIM and NMDS reveal that the two species did not differ with respect to the composition of co-occurring vascular plant species. On the other hand, the distributions of these species were well modelled using geographical space. Specifically, the location of initial infestation sites, prior to the rapid spread phase on invasion (Fig. 1b), was well correlated with the present-day distribution of species. This suggests that the observed pattern resulted from a limitation in the local distribution within the invaded ranges. However, these species are known to have efficient long-range dispersal (Weber 2000; Weber and Jakobs 2005). We suggest that priority effect limited goldenrod distributions (Shulman et al. 1983; Vannette and Fukami 2014); that is, the 

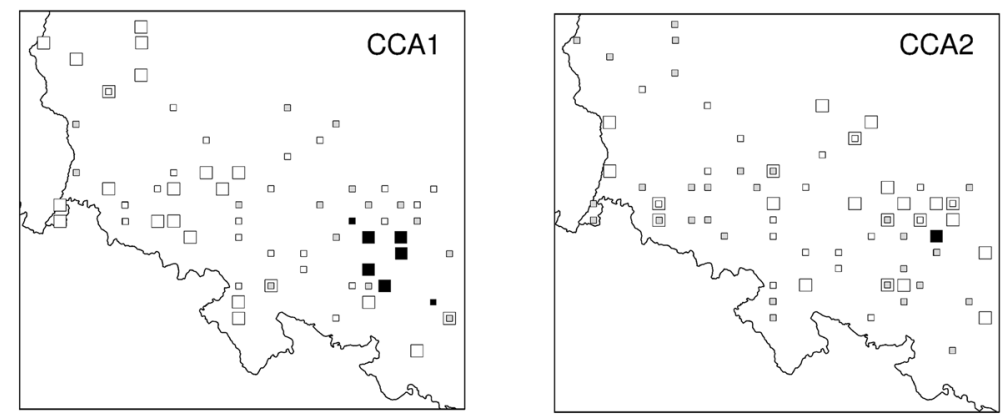

high negative site score

high positive site score

environment
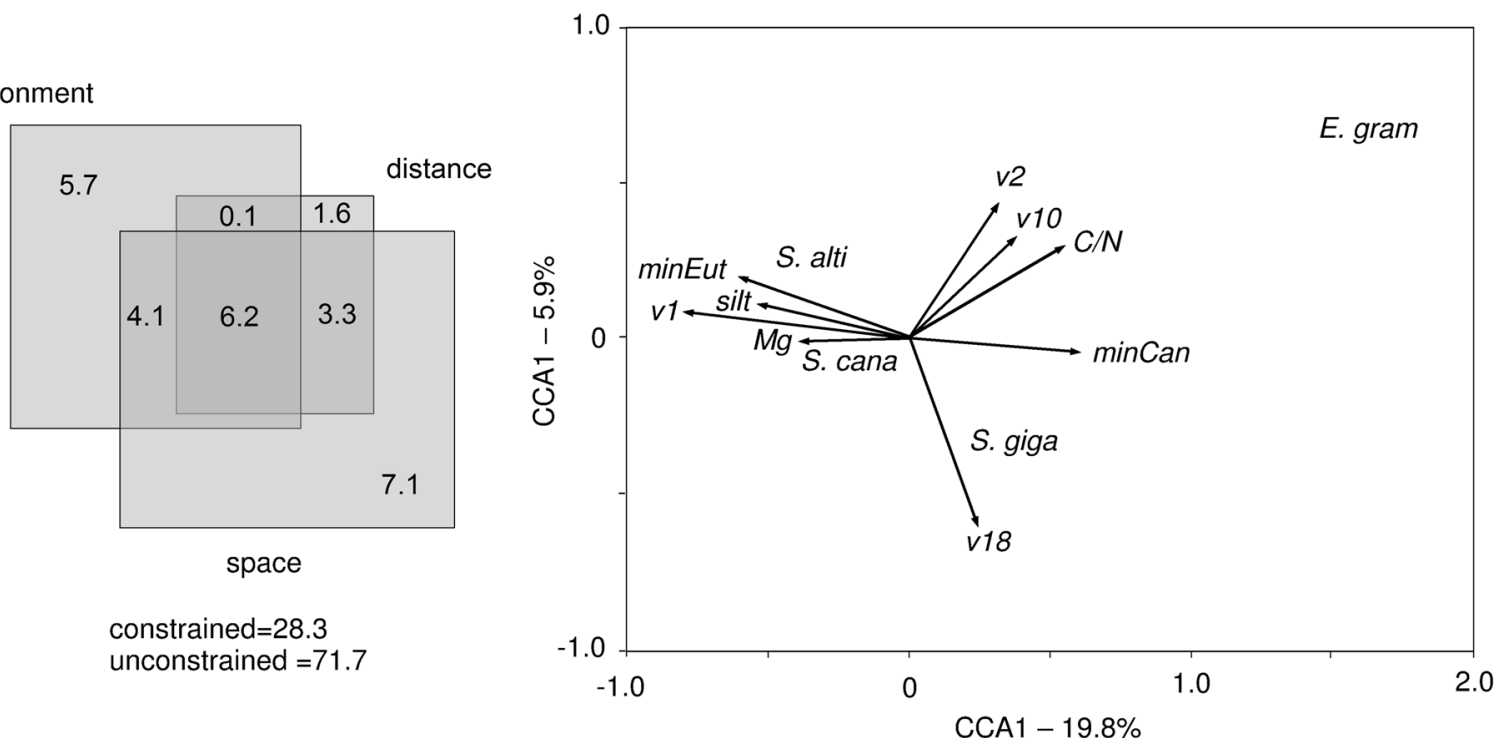

Fig. 7 Results of CCA ordination for topsoil subset. On the upper panel, the values of site scores of CCA with exclusively spatial variables as constraints plotted against geographical coordinates of plots are shown. The lower panel shows the results for the combined model (space, environment and distance) of alien goldenrod distribution: the variation

goldenrod species that first occupied the particular area blocked the establishment of further species from seeds. In subsequent stages, the populations produce a large number of diaspores that increase the probability of invasion of the remaining suitable habitats within the neighbourhood (Meyer and Schmid 1999a). Results of garden experiments showed that the two species are similar with respect to their competitiveness (Szymura and Szymura 2016); thus, the competitive exclusion of one species by another is not likely during later stages of invasion. In addition, the probability that new species could establish from seeds in a dense, well-established stand is minimal (Hartnett and Bazzaz 1985; Meyer and Schmid partitioning results on the left and the CCA biplot on the right. minCan the shortest distance to the initial infestation location from $S$. canadensis s.1. plots; minEut the shortest distance to the initial infestation location from E. graminifolia plots, E. gram E. graminifolia, S. alti S. altissima, S. cana S. canadensis, S. giga $S$. gigantea, V1-V18 PCNM vectors

1999a). In the case of S. altissima, the proportion of seeds germinated in patches of vegetation was $0.008 \%$; however, the emergence of seedlings in artificially created openings was high (Meyer and Schmid 1999a). The authors concluded that offspring coming from seeds did not influence the dynamics of established populations of S. altissima but, most probably, are important in colonisation of new, open habitats with disturbed soil. As a result, we observed regions dominated by either $S$. altissima or $S$. gigantea. The association of $S$. gigantea with river valleys seems to be the effect of early colonisation patterns, rather than strict preferences for wet habitats in Central Europe. 


\section{Euthamia graminifolia}

This species outstand from the other goldenrod species as it was under-represented on abandoned lands, key habitats of invasive Solidago in Central Europe and did not tend to avoid forests. This species was also more frequent within linear habitats such as road verges and unpaved roads. This suggests that the species is more shade tolerant than the others and is perhaps less efficient in colonisation and occupation of open habitats. In contrast, in the native range, it is a typical species of open prairie landscape (Parker et al. 1993; Lake et al. 2014). In garden experiments, this species is highly competitive and can significantly decrease the biomass of S. altissima and S. gigantea through underground competition (Szymura and Szymura 2016). Therefore, its under-representation in open areas is more likely attributed to the limited longrange distribution of this species and to low seed germination in the new range. The proportion of germinating $E$. graminifolia seeds in the native range of Canada reaches $78 \%$ (White et al. 2009), but in Europe, very few mature seeds could germinate, compared to the much higher percentages of $S$. altissima and S. gigantea (Voser-Huber 1983; Szymura 2012). Moreover, many of the abandoned fields in the studied region were already occupied by $S$. gigantea, which would additionally limit the expansion of E. graminifolia. Low germination of $E$. graminifolia is compensated by efficient re-growth by rhizomes, which comprises a significant part of the clonal biomass (Szymura and Szymura 2015). Thus, its over-representation on linear habitats can be attributed to the vegetative spread along road verges and unpaved roads. Ineffective long-range dispersal also explained the limited range of its distribution, which did not expand considerably since the initial establishment in Europe (Guzikowa and Maycock 1986; Weber 2001). There were also likely fewer $E$. graminifolia introduction sites, compared to the other species as it is considered less ornamental than $S$. altissima and $S$. gigantea and has been less frequently used in horticulture (Weber and Schmid 1998; Weber 2001). In Silesia, its propagules were probably transported accidentally along with ornamental trees into the local arboretum (Dajdok and Nowak 2007). E. graminifolia is sporadically reported from open abandoned fields and new localities of this species have been found (Kompała-Bạba and Bạba 2006; Dajdok and Nowak 2007), suggesting that the species may overcome the dispersal barrier to invasion (Szymura and Szymura 2013).

The results suggest differences in ecological niche of E. graminifolia compared to the Solidago species. However, the fraction of variability shared by space, environment and distance in the topsoil model was high. Thus, the presence of E. graminifolia on more shaded habitats, on sandy soils with a high $\mathrm{C} / \mathrm{N}$ ratio and low content of $\mathrm{K}$ and $\mathrm{Mg}$, as well as higher minimal temperature, cannot unequivocally be considered as its ecological optima. The observed pattern could also result from both limited distribution and priority effects. The potential European range of $E$. graminifolia, determined on the basis of its climatic preferences, is comparable to other goldenrods (Weber 2001). In North America, this species occupies areas with slightly lower temperatures than the areas occupied by $S$. altissima and S. gigantea (Weber 2001). In Silesia, we observed an opposite temperature reaction. However, these differences appear to be caused mostly by its limited distribution, because $E$. graminifolia sites were exclusively within the lowland part of the region, where the minimal temperatures are higher than those in highland areas. Moreover, the differences in soil chemical composition can be attributed to typical properties of forest soils, on which E. graminifolia was most commonly found, while the remaining species often invaded more fertile post-agricultural lands.

\section{Solidago canadensis}

Solidago is known as one of the most complex genera of higher plants, and its variability has further increased due to hybridisation, introgression and ecological factors (Beaudry and Chabot 1957; Beaudry 1963; Weber 1997). In the native range, $S$. canadensis consists of diploid $(2 n=18)$ and tetraploid plants $(2 n=36)$, while $S$. altissima consists of hexaploid $(2 n=54)$, triploid $(2 n=27)$ and tetraploid $(2 n=36)$ cytotypes (Semple et al. 1981, 1984, 2015). Both taxa, S. canadensis var. canadensis and $S$. altissima, were introduced from North America to Europe (Wagenitz 1979; Weber 1997). However, in Europe, the taxonomical status of $S$. canadensis and $S$. altissima is unclear, because both are represented exclusively by diploids (Weber 2000). These species can form hybrids in the native range. Hybridisation has 
also been observed in Europe between $S$. canadensis s.l. and native S. virgaurea (Pliszko 2013; Migdałek et al. 2014). Thus, it could be also hypothesised that the random pattern of $S$. canadensis distribution, overlapping extensively with the ranges of S. altissima and $S$. gigantea, could be related to the hybrid nature of this species. However, the populations examined here were checked for their chromosome number (Szymura et al. 2015), and the results showed that all S. canadensis and S. altissima were exclusively diploids, whereas $S$. gigantea was tetraploid. These findings allow us to reject the hypothesis about the hybrid nature of local $S$. canadensis. The traits used to distinguish $S$. altissima and $S$. canadensis primarily refer to the presence or absence of hairs on stems and leaves as well as leaf epidermis (Weber 1997; Semple and Cook 2006; Szymura and Wolski 2011). Therefore, they could not be considered as functional traits, which influence the fitness and competitiveness of individuals, and are likely not under natural selection. $S$. altissima and $S$. canadensis did not differ in functional traits, biomass production and allocation, as well as ploidy levels (Szymura and Szymura 2013, 2015; Szymura et al. 2015). These findings, in combination with results of this study, suggest that all the Solidago plants with more or less hairy stems in Central Europe may be considered as one complex species, S. canadensis s.1., without differences in their ecology and most likely their environmental impact.

Acknowledgments The study was supported by Grants: NCN (N N305 401438), the Wrocław University of Environmental and Life Sciences, and the University of the Wrocław. The authors thank the Editor and Anonymous Reviewers for their comments, which helped us to improve the manuscript.

Open Access This article is distributed under the terms of the Creative Commons Attribution 4.0 International License (http:// creativecommons.org/licenses/by/4.0/), which permits unrestricted use, distribution, and reproduction in any medium, provided you give appropriate credit to the original author(s) and the source, provide a link to the Creative Commons license, and indicate if changes were made.

\section{References}

Abrahamson WG, Dobley KB, Houseknecht HR, Pecone CA (2005) Ecological divergence among five co-occurring species of old-field goldenrods. Plant Ecol 177:43-56

Bartha S, Szentes S, Horváth A, Házi J, Zimmermann Z, Molnár C, Dancza I, Margóczi K, Pál RW, Purger D, Schmidt D,
Óvári M, Komoly C, Sutyinszki Z, Szabó G, Csathó AI, Juhász M, Penksza K, Molnár Z (2014) Impact of midsuccessional dominant species on the diversity and progress of succession in regenerating temperate grasslands. Appl Veg Sci 17:201-213

Beaudry JR (1963) Studies on Solidago L. VI. Additional chromosome numbers of taxa of the genus Solidago. Can J Genet Cytol 5(2):150-174

Beaudry JR, Chabot DL (1957) Studies on Solidago L. I. S. altissima L. and $S$. canadensis L. Contrib Inst Bot Univ Montr Que 70:65-72

Borcard D, Legendre P (2002) All-scale spatial analysis of ecological data by means of principal coordinates of neighbor matrices. Ecol Model 153:51-68

Borcard D, Legendre P, Drapeau P (1992) Partialling out the spatial component of ecological variation. Ecology 73:1045-1055. doi:10.2307/1940179

Borcard D, Legendre P, Avois-Jacquet C, Tuomisto H (2004) Dissecting the spatial structure of ecological data at multiple scales. Ecology 85:1826-1832

Bornkamm R (2007) Spontaneous development of urban woody vegetation on differing soils. Flora 202:695-704

Cain ML (1990) Patterns of Solidago altissima ramet growth and mortality: the role of below-ground ramet connections. Oecologia 82(2):201-209

Carson WP, Root RB (2000) Herbivory and plant species coexistence: community regulation by an outbreaking phytophagous insect. Ecol Monogr 70(1):73-99

Catford JA, Jansson R, Nilsson C (2009) Reducing redundancy in invasion ecology by integrating hypotheses into a single theoretical framework. Divers Distrib 15:22-40

Chamberlain SA, Bronstein JL, Rudgers JA (2014) How context dependent are species interactions? Ecol Lett 17:881-890

Chapuis-Lardy L, Vanderhoeven S, Dassonville N, Koutika LS, Meerts P (2006) Effect of the exotic invasive plant Solidago gigantea on soil phosphorus status. Biol Fertil Soils 42(6):481-489

Chytrý M, Jarosik V, Pysek P, Hajek O, Knollová I, Tichý L, Danihelka J (2008) Separating habitat invasibility by alien plants from the actual level of invasion. Ecology 89:1541-1553

Dajdok Z, Nowak A (2007) Solidago graminifolia (L.) Elliott in Poland-spreading and habitat preferences. In: TokarskaGuzik B et al (eds) Plant invasions: human perception, ecological impacts and management. Backhuys Publishers, Leiden, pp 101-116

Del Fabbro C, Güsewell S, Prati D (2013) Allelopathic effects of three plant invaders on germination of native species: a field study. Biol Invasions 16:1035-1042

Dray S, Legendre P, Peres-Neto PR (2006) Spatial modelling: a comprehensive framework for principal coordinate analysis of neighbour matrices (PCNM). Ecol Model 196:483-493

Essl F, Dullinger S, Rabitsch W, Hulme PE, Hülber K, Jarošík V, Kleinbauer I, Krausmann F, Kühn I, Nentwig W, Vilà M, Genovesi P, Gherardi F, Desprez-Loustau ML, Roques A, Pyšek P (2011) Socioeconomic legacy yields an invasion debt. Proc Natl Acad Sci USA 108(1):203-207

Fenesi A, Vágási CI, Beldean M, Földesi R, Kolcsár LP, Shapiro JT, Török E, Kovács-Hostyánszki A (2015a) Solidago canadensis impacts on native plant and pollinator 
communities in different-aged old fields. Basic Appl Ecol 16(4):335-346

Fenesi A, Geréd J, Meiners SJ, Tóthmérész B, Török P, Ruprecht E (2015b) Does disturbance enhance the competitive effect of the invasive Solidago canadensis on the performance of two native grasses? Biol Invasions 17(11):3303-3315

Fraser CI, Banks SC, Waters JM (2015) Priority effects can lead to underestimation of dispersal and invasion potential. Biol Invasions $17(1): 1-8$

Fukami T (2010) Community assembly dynamics in space. In: Verhoef HA, Morin PJ (eds) Community ecology: processes, models, and applications. Oxford University Press, Oxford, pp 45-54

Gioria M, Osborne BA (2014) Resource competition in plant invasions: emerging patterns and research needs. Front Plant Sci 5:501

Grman E, Suding KN (2010) Within-year soil legacies contribute to strong priority effects of exotics on native California grassland communities. Restor Ecol 18(5):664-670

Güsewell S, Zuberbühler N, Clerc C (2005) Distribution and functional traits of Solidago gigantea in a Swiss lakeshore wetland. Bot Helv 115(1):63-75

Guzikowa M, Maycock PF (1986) The invasion and expansion of three North American species of goldenrod (Solidago canadensis L. sensu lato, S. gigantea Ait. and S. graminifolia (L.) Salisb.) in Poland. Acta Soc Bot Pol 55:367-384

Hartnett DC, Bazzaz FA (1985) The genet and ramet population dynamics of Solidago canadensis in an abandoned field. J Ecol 73:407-413

Hejda M, Pyšek P, Jarošík V (2009) Impact of invasive plants on the species richness, diversity and composition of invaded communities. J Ecol 97(3):393-403

Hijmans RJ, Cameron SE, Parra JL, Jones PG, Jarvis A (2005) Very high resolution interpolated climate surfaces for global land areas. Int J Climatol 25(15):1965-1978

Hitchmough J, De La Fleur M, Findlay C (2004) Establishing North American prairie vegetation in urban parks in northern England. Part 1. Effect of sowing season, sowing rate and soil type. Landsc Urban Plan 66:75-90

Hollander M, Wolfe DA (1999) Nonparametric statistical methods, 2nd edn. Wiley, New York

Hothorn T, Hornik K, van de Wiel MA, Zeileis A (2013) Package 'coin'. Conditional inference procedures in a permutation test framework. http://cran.r-project.org/web/ packages/coin/coin.pdf. Accessed Sept 2015

Hulme PE, Pyšek P, Pergl J, Jarošík V, Schaffner U, Vilà M (2014) Greater focus needed on alien plant impacts in protected areas. Conserv Lett 7(5):459-466

Hulme PE, Pauchard A, Pyšek P, Vilà M, Alba C, Blackburn TM, Bullock JM, Chytrý M, Dawson W, Dunn AM, Essl F, Genovesi P, Maskell LC, Meyerson LA, Nuñez MA, Pergl J, Pescott OL, Pocock MJO, Richardson DM, Roy HE, Smart SM, Štajerová K, Stohlgren T, van Kleunen M, Winter M (2015) Challenging the view that invasive nonnative plants are not a significant threat to the floristic diversity of Great Britain. Proc Natl Acad Sci USA 112(23):E2988-E2989

Jarvis A, Reuter HI, Nelson A, Guevara E (2008) Hole-filled SRTM for the globe version 4. Available from the
CGIAR-CSI SRTM 90m database. http://srtm.csi.cgiar. org. Accessed Sept 2015

Johnson LE, Brawley SH, Adey WH (2012) Secondary spread of invasive species: historic patterns and underlying mechanisms of the continuing invasion of the European rockweed Fucus serratus in eastern North America. Biol Invasions 14(1):79-97

Kącki Z, Śliwinski M (2012) The Polish Vegetation Database: structure, resources and development. Acta Soc Bot Pol 81(2):75-79

Kardol P, Souza L, Classen AT (2013) Resource availability mediates the importance of priority effects in plant community assembly and ecosystem function. Oikos 122(1):84-94

Kompała-Bąba A, Bąba W (2006) Solidago graminifolia (L.) Elliott on anthropogenic sites of the Silesian Upland Poland. Biodivers Res Conserv 3-4:329-332

Kuebbing SE, Nuñez MA (2015) Negative, neutral, and positive interactions among nonnative plants: patterns, processes, and management implications. Glob Change Biol 21(2):926-934

Kuebbing SE, Nuñez MA, Simberloff D (2013) Current mismatch between research and conservation efforts: the need to study co-occurring invasive plant species. Biol Conserv 160:121-129

Lake JC, Leishman MR (2004) Invasion success of exotic plants in natural ecosystems: the role of disturbance, plant attributes and freedom from herbivores. Biol Conserv 117(2):215-226

Lake EC, Hough-Goldstein J, D'Amico V (2014) Integrating management techniques to restore sites invaded by mile-aminute weed, Persicaria perfoliata. Restor Ecol 22(2):127-133

Láníková D, Chytrý M, Lososová Z (2009) Xerophilous ruderal vegetation with biennial and perennial species. In: Chytrý M (ed) Vegetation of the Czech Republic. 2 Ruderal weed rock scree vegetation. Academia, Praha, pp 206-288

Levine JM, Vila M, Antonio CM, Dukes JS, Grigulis K, Lavorel S (2003) Mechanisms underlying the impacts of exotic plant invasions. Proc R Soc Lond B 270:775-781

Marchante H, Marchante E, Freitas H, Hoffmann JH (2015) Temporal changes in the impacts on plant communities of an invasive alien tree, Acacia longifolia. Plant Ecol 216(11):1481-1498

Meyer A, Schmid B (1999a) Seed dynamics and seedling establishment in the invading perennial Solidago altissima under different experimental treatments. J Ecol 87(1):28-41

Meyer A, Schmid B (1999b) Experimental demography of the old-field perennial Solidago altissima: the dynamics of the shoot population. J Ecol 87(1):17-27

Migdałek G, Kolczyk J, Pliszko A, Kościńska-Pająk M, Słomka A (2014) Reduced pollen viability and achene development in Solidago $\times$ niederederi Khek from Poland. Acta Soc Bot Pol 83(3):251-255

Miller NP, Matlack GR (2010) Biodiversity research: population expansion in an invasive grass, Microstegium vimineum: a test of the channeled diffusion model. Divers Distrib 16(5):816-826

Mirek Z, Piękoś-Mirkowa H, Zając A, Zając M (2002) Flowering plants and pteridophytes of Poland a checklist. In: 
Mirek Z (ed) Biodiversity of Poland, vol 1. W. Szafer Institute of Botany, Polish Academy of Sciences, Cracow

Moroń D, Lenda M, Skórka P, Szentgyörgyi H, Settele J, Woyciechowski M (2009) Wild pollinator communities are negatively affected by invasion of alien goldenrods in grassland landscapes. Biol Conserv 142:1322-1332

Oksanen J, Kindt R, Legendre P, O'Hara B, Simpson GL, Solymos P, Stevens MHH, Wagner H (2008) Vegan community ecology package. R package version $1.15-0$. http://cran.r-project.org/, http://vegan.rforger-project.org. Accessed Sept 2015

Pal RW, Chen S, Nagy DU, Callaway RM (2015) Impacts of Solidago gigantea on other species at home and away. Biol Invasions 17(11):3317-3325

Parker IM, Mertens SK, Schemske DW (1993) Distribution of seven native and two exotic plants in a tallgrass prairie in southeastern Wisconsin: the importance of human disturbance. Am Midl Nat 130:43-55

Pejchar L, Mooney HA (2009) Invasive species, ecosystem services and human well-being. Trends Ecol Evol 24:497-504

Peres-Neto P, Legendre P, Dray S, Borcard D (2006) Variation partitioning of species data matrices: estimation and comparison of fractions. Ecology 87:2614-2625

Pliszko A (2013) A new locality of Solidago $\times$ niederederi Khek (Asteraceae) in Poland. Biodivers Res Conserv 29:57-62

Putten WH, Bardgett RD, Bever JD, Bezemer TM, Casper BB, Fukami T, Kardol P, Klironomos JN, Kulmatiski A, Schweitzer JA, Suding KN (2013) Plant-soil feedbacks: the past, the present and future challenges. J Ecol 101(2):265-276

Pyšek P (1998) Alien and native species in Central European urban floras: a quantitative comparison. J Biogeogr 25:155-163

Pyšek P, Richardson DM (2008) Invasive plants. In: Jørgensen SE, Fath BD (eds) Ecological engineering. Encyclopedia of ecology, vol 3. Elsevier, Oxford, pp 2011-2020

Pyšek P, Richardson DM (2010) Invasive species, environmental change and management, and health. Annu Rev Environ Resour 35:25-55

Rhoads AF, Block TA (2000) The plants of Pennsylvania: an illustrated manual. University of Pennsylvania Press, Philadelphia

Ricklefs RE (2010) Dynamics of colonization and extinction on islands: insights from Lesser Antillean birds. In: Losos JB, Ricklefs RE (eds) The theory of island biogeography revisited. Princeton University Press, Princeton, pp 388-414

Rosenberg MS, Anderson CD (2011) PASSaGE: pattern analysis, spatial statistics and geographic exegesis. Version 2. Method Ecol Evol 2(3):229-232

Schlaepfer DR, Edwards PJ, Semple CJ, Billeter R (2008) Cytogeography of Solidago gigantea (Asteraceae) and its invasive ploidy level. J Biogeogr 35:2119-2127

Schmid B, Puttick GM, Burgess KH, Bazzaz FA (1988) Correlations between genet architecture and some life history features in three species of Solidago. Oecologia 75:459-464

Semple JC, Cook RE (2006) Solidago. In: Flora North America Editorial Committee (ed) Flora of North America. Asteraceae, part 2. Astereae and Senecioneae, vol 20. Oxford University Press, Oxford, pp 107-166
Semple JC, Brammall RA, Chmielewski J (1981) Chromosome numbers of goldenrods, Euthamia and Solidago (Compositae-Asteraceae). Can J Bot 59:1167-1173

Semple JC, Ringius GS, Leeder C, Morton G (1984) Chromosome numbers of goldenrods, Euthamia and Solidago (Compositae-Asteraceae). II. Additional counts with comments on cytogeography. Brittonia 36:280-292

Semple JC, Rahman H, Bzovsky S, Sorour MK, Kornobis K, Lopez Laphitz R, Tong L (2015) A multivariate morphometric study of the Solidago altissima complex and $S$. canadensis (Asteraceae: Astereae). Phytoneuron 2014(10): $1-31$

Sheppard AW, Shaw RH, Sforza R (2006) Top 20 environmental weeds for classical biological control in Europe: a review of opportunities, regulations and other barriers to adoption. Weed Res 46(2):93-117

Shulman MJ, Ogden JC, Ebersole JP, McFarland WN, Miller SL, Wolf NG (1983) Priority effects in the recruitment of juvenile coral reef fishes. Ecology 64:1508-1513

Skórka P, Lenda M, Tryjanowski P (2010) Invasive alien goldenrods negatively affect grassland bird communities in Eastern Europe. Biol Conserv 143:856-861

Szymura M (2012) Ocena zdolności do rozmnażania generatywnego i wegetatywnego nawłoci występujących w południowo-zachodniej Polsce. Zesz Nauk Uniw Przyr we Wroc 585:103-112 (in Polish with English abstract)

Szymura M, Szymura TH (2011) Rozmieszczenie nawłoci (Solidago spp.) na obszarze Dolnego Śląska oraz ich wpływ na różnorodność biologiczną zasiedlanych fitocenoz. Acta Bot Sil 6:195-212 (in Polish with English abstract)

Szymura M, Szymura TH (2013) Soil preferences and morphological diversity of goldenrods (Solidago L.) from south-western Poland. Acta Soc Bot Pol 82(2):107-115

Szymura M, Szymura TH (2015) Growth, phenology, and biomass allocation of alien Solidago species in Central Europe. Plant Species Biol 30:245-256

Szymura M, Szymura TH (2016) Interactions between alien goldenrods (Solidago and Euthamia species) and comparison with native species in Central Europe. Flora 218:51-61

Szymura M, Wolski K (2011) Leaf epidermis traits as tools to identify Solidago L. taxa in Poland. Acta Biol Crac Bot 53(1):38-46

Szymura M, Szymura TH, Kreitschitz A (2015) Morphological and cytological diversity of goldenrods (Solidago L. and Euthamia Nutt.) from south-western Poland. Biodivers Res Conserv 38:41-49

Tokarska-Guzik B (2003) The expansion of some alien plant species (neophytes) in Poland. In: Child L, Brock JH, Brundu G, Prach K, Pyšek P, Wade PM, Williamson M (eds) Plant invasions: ecological treats and management solutions. Backhuys Publishers, Leiden, pp 147-167

Van Kleunen M, Weber E, Fischer M (2010) A meta-analysis of trait differences between invasive and non-invasive plant species. Ecol Lett 13(2):235-245

Vannette RL, Fukami T (2014) Historical contingency in species interactions: towards niche-based predictions. Ecol Lett 17(1):115-124

Vilá M, Weiner J (2004) Are invasive species better competitors than native plant species? Evidence from pair-wise experiments. Oikos 105:229-238 
Vilà M, Espinar JL, Hejda M, Hulme PE, Jarošík V, Maron JL, Pyšek P (2011) Ecological impacts of invasive alien plants: a meta-analysis of their effects on species, communities and ecosystems. Ecol Lett 14:702-708

Voser-Huber MI (1983) Studien an eingebürgerten Arten der Gattung Solidago L. Diss Bot 68:1-97

Wagenitz G (1979) Solidago L. In: Hegi G (ed) Illustrierte Flora von Mitteleuropa, vol VI (3.1). Carl Hanser, München, p 16-29

Wangen SR, Webster CR (2006) Potential for multiple lag phases during biotic invasions: reconstructing an invasion of the exotic tree Acer platanoides. J Appl Ecol 43(2):258-268

Warren RJ, Ursell T, Keiser AD, Bradford MA (2013) Habitat, dispersal and propagule pressure control exotic plant infilling within an invaded range. Ecosphere 4(2):1-12

Weber E (1997) Morphological variation of the introduced perennial Solidago canadensis L. sensu lato (Asteraceae) in Europe. Bot J Linn Soc 123:197-210

Weber E (2000) Biological flora of Central Europe: Solidago altissima L. Flora 195:123-134

Weber E (2001) Current and potential ranges of three exotic goldenrods (Solidago) in Europe. Conserv Biol 15(1):122-128

Weber E (2003) Invasive plant species of the world. A reference guide to environmental weeds. CABI Publishing, Oxon

Weber E (2011) Strong regeneration ability from rhizome fragments in two invasive clonal plants (Solidago canadensis and S. gigantea). Biol Invasions 13(12):2947-2955
Weber E, Jakobs G (2005) Biological flora of Central Europe: Solidago gigantea Aiton. Flora 200:109-118

Weber E, Schmid B (1998) Latitudinal population differentiation in two species of Solidago (Asteraceae) introduced into Europe. Am J Bot 85:1110-1121

White AL, Boutin C, Dalton RL, Henkelman B, Carpenter D (2009) Germination requirements for 29 terrestrial and wetland wild plant species appropriate for phytotoxicity testing. Pest Manag Sci 65(1):19-26

Whitham TG (1983) Host manipulation of parasites: withinplant variation as a defense against rapidly evolving pests. In: Variable plants and herbivores in natural and managed systems. Academic, New York, p 15-41

Wise MJ, Abrahamson WG, Landis K (2006) Edaphic environment, gall midges, and goldenrod clonal expansion in a mid-successional old-field. Acta Oecol 30(3):365-373

Young TP, Zefferman EP, Vaughn KJ, Fick S (2015) Initial success of native grasses is contingent on multiple interactions among exotic grass competition, temporal priority, rainfall and site effects. AoB Plants 7:plu081

Zefferman EP (2015) Experimental tests of priority effects and light availability on relative performance of Myriophyllum spicatum and Elodea nuttallii propagules in artificial stream channels. PLoS One 10(3):e0120248 